\title{
Diversity and Abundance of Rotifera in Kadıköy Reservoir of Turkey
}

\section{Hüseyin GÜHER ${ }^{1 *}$}

\begin{abstract}
This research has been carried out to determine diversity and abundance of Rotifera in Kadıköy Reservoir. For this purpose, Rotifera and water samples were collected monthly from March 2010 to February 2011 at three different stations in the reservoir. A total of 33 species from Rotifera were determined in the qualitative evaluation of samples taken from the reservoir. The quantitative evaluation of the Rotifera samples revealed presence of an average of 70472 ind $\mathrm{m}^{-3}$ in Kadıköy Reservoir. The maximum number of Rotifera were recorded at $1^{\text {st }}$ station (81 819 ind $\mathrm{m}^{-3}$ ); in May

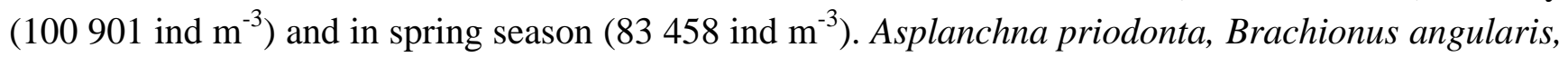
Filinia terminalis and Keratella cochlearis sampling in all months were found to be the most common species during the study. When we evaluate the species identified in the reservoir, the distribution of the individuals that make up the Rotifera fauna and physical-chemical parameters as a whole, it has been concluded that Kadıköy Reservoir is in meso-eutrophic character in terms of Rotifera.
\end{abstract}

Keywords: Rotifera, species diversity, water quality, reservoir.

\section{Kadıköy Barajı’nın (Türkiye) Rotifera Bolluğu ve Tür Çeşitliliği}

ÖZET: Bu araştırma, Kadıköy baraj gölünün Rotifera faunasını ve kommunite yapısını belirlemek amacıyla yapılmıştır. Araştırmada Kadıköy Barajı'nda belirlenen 3 istasyonda Mart 2010-Şubat 2011 tarihleri arasında Rotifera örnekleri toplanırken bu organizmaları etkileyen bazı çevresel parametrelerde ölçülmüştür. Toplanan örneklerin değerlendirmesi sonucunda 33 Rotifera türü tespit edilirken Kadıköy Baraj Gölü’nde yıllık ortalama 70472 birey $\mathrm{m}^{-3}$ bulunmuştur. En fazla birey 1 .

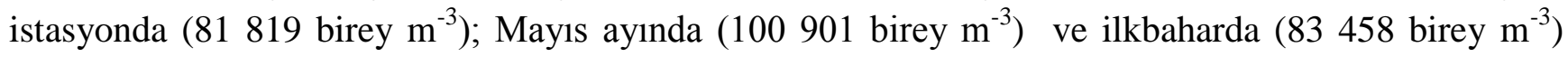
bulunmuştur. Çalışma süresince tüm aylarda bulunan Asplanchna priodonta, Brachionus angularis, Filinia terminalis ve Keratella cochlearis en yaygın türler olarak tespit edilmiştir. Baraj gölü’nde tespit edilen Rotifera türlerine ve ölçülen fizikokimyasal parametrelere göre Kadıköy Baraj Gölü'nün mezo-ötrofik karakterde olduğu belirlenmiştir.

Anahtar Kelimeler: Rotifera, tür çeşitliliğgi, su kalitesi, baraj gölü.

\footnotetext{
${ }^{1}$ Hüseyin Güher (Orcid ID: 0000-0001-6206-0912), Trakya University, Faculty of Science, Department of Biology, Edirne, Turkey. 


\section{INTRODUCTION}

In fresh water ecosystems, phytoplanktonic organisms constitute an important food source of some aquatic invertebrate, whereas zooplanktonic organisms are an important food source of both aquatic invertebrate and fish larvae. The typical zooplankton assemblage in fresh water ecosystem commonly consists of Rotifera, Copepoda, Cladocera and Protozoa (Rocha et al., 1999). Rotifera is always the dominant group among the others, depending on the physicochemical and biological properties of the aquatic ecosystem. Rotifera can be found in various aquatic habitats such as lakes, pools, streams and puddles and provide food for vertebrate and invertebrate animals. Also bdelloid rotifers and some species of Dicranophoridae live in terrestrial habitats such as moss, liken, soil and bark.

The abundance and composition of Rotifer species in freshwater ecosystems provide important information in determining the productivity of the aquatic ecosystems. Rotifera are also used as indicator organisms for pollution and eutrophication for the habitat they are present in since they are more susceptible to ecosystem alteration compared to other zooplanktonic groups. The zooplankton composition, distribution, diversity and relative abundance of a reservoir can have significant impact on fisheries in reservoir. The diversity and abundance of zooplankton in reservoir often differ according to the physicochemical and biological structure of the reservoir (Jackson and Schmitz, 1987; Sampaio et al., 2002). For this reason, in order to understand the productivity of an aquatic environment, the Rotifer species and its abundance must be well examined and determined. Rotifera species, distribution and diversity in inland waters in Turkey have been carried out a number of studies to examine. (Ustaoğlu, 2004; Ustaoğlu et al., 2012; Erdoğan and Güher, 2012; Güher, 2014). Some other studies particularly paid to Rotifera in various reservoirs in Turkey. (Bekleyen, 2003; Kaya and Altındağ, 2007; Bozkurt and Sagat, 2008; Dirican and Musul, 2008; Mis and Aygen; 2010; Ayvaz et al., 2011; Y1ld1z, 2012; Buyurgan, 2010; Bulut and Saler, 2014; Saler and Alış, 2014; Tuna and Ustaoğlu, 2016 and Saler, 2017). This study was conducted to identify the Rotifera fauna of Kadıköy Reservoir located in Keşan District of Edirne province, Turkey and to reveal the species composition and richness.

\section{MATERIALS AND METHODS}

Study Area: Kadıköy Reservoir is located $20 \mathrm{~km}$ far to the south-east of Keşan district in Edirne province, Turkey $\left(40^{0} 48^{\prime} 51^{\prime}, \mathrm{N}, 26^{0}\right.$ $47^{\prime} 43^{\prime}$ 'E). It was built for flood control and irrigation purposes and also provides drinking and domestic water of Keşan district. It has a maximum depth of $20 \mathrm{~m}$ and a surface area of $6.2 \mathrm{~km}^{2}$. Although the reservoir is fed mainly by the Doğanca Stream, it is also replenished by other small streams in the region and rainfall (Figure 1).

Sampling: The samples were collected monthly from March 2010 to February 2011 in three different points in reservoir (Figure 1). Because of harsh weather conditions, no sampling could be performed in January 2011. The $1^{\text {st }}$ sampling station was located where the water gathered, the $2^{\text {nd }}$ sampling station was located in the middle of the reservoir and the $3^{\text {rd }}$ sampling station was the shallowest part of the reservoir. Rotifer samples were collected with a Hensen type plankton net (mesh size $55 \mu$, mouth diameter $15 \mathrm{~cm}$, length $75 \mathrm{~cm}$ ). The samples were carried to the laboratory in $250 \mathrm{~mL}$ plastic bottles containing $4 \%$ of formaldehyde solution. In the laboratory, the samples were identified according to Ruttner-Kolisko (1974), Koste (1978), Herzig (1987), De Manuel Barrabin (2000), Segers (2008) and Ustaoğlu et al. (2012) and their counting was done according to Edmondson (1959) using an Olympus 
inverted microscope. Some physicochemical parameters, such as water temperature, light permeability, conductivity, $\mathrm{pH}$, dissolved oxygen were measured on site simultaneously with the sampling time. For other physicalchemical features of the water, water samplings were taken by a Ruttner water sampler in the reservoir. The values of $\mathrm{PO}_{4}{ }^{-3}$ (Phosphate), $\mathrm{NO}_{3}{ }^{-}$ $-\mathrm{N}$ (Nitrate-nitrogen), $\mathrm{NO}_{2}-\mathrm{N}$ (Nitrite-nitrogen),
$\mathrm{SO}_{4}{ }^{2-} \quad$ (Sulphate), $\quad \mathrm{Ca} \quad$ (Calcium), $\quad \mathrm{Mg}$ (Magnesium), $\mathrm{Cl}$ (Chloride) were measured in laboratories of Trakya University Technology Research Development Application and Research Center (TUTAGEM).

Bray-Curtis Similarity index was used to examine the similarities of sampling months and seasons with respect according to diversity and abundance of Rotifera species (Krebs 1999).

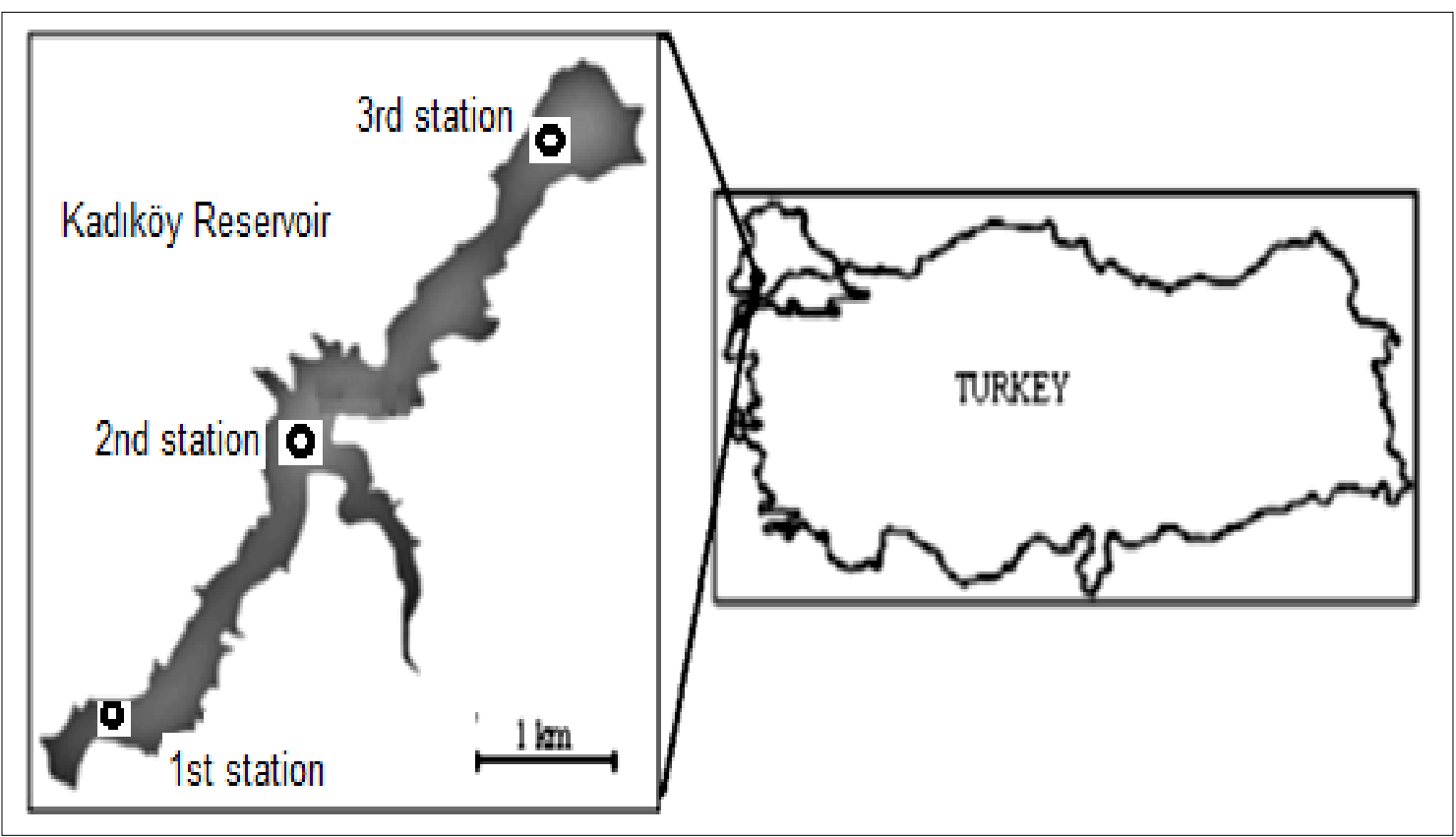

Figure 1: The location of Kadıköy Reservoir and the sampling points

\section{RESULTS AND DISCUSSION}

Physical and Chemical Variables: The minimum and maximum values of environmental parameters measured in the Kadıköy Reservoir were as follows; water temperature: $2.00-29.00\left({ }^{0} \mathrm{C}\right)$; DO: $3.40-15.73$ $\left(\mathrm{mg} \mathrm{L}^{-1}\right)$; $\mathrm{pH}:$ 7.53-8.63; EC: 388.00-613.67 $(\mu \mathrm{S}$ $\left.\mathrm{cm}^{-1}\right) ; \mathrm{NO}_{2}-\mathrm{N}: 0.00-0.09\left(\mathrm{mg} \mathrm{L}^{-1}\right) ; \mathrm{NO}_{3}-\mathrm{N}: 0.00-$ $9.89\left(\mathrm{mg} \mathrm{L}^{-1}\right)$; $\mathrm{PO}_{4}-\mathrm{P}: 0.00-0.068\left(\mathrm{mg} \mathrm{L}^{-1}\right)$; $\mathrm{SO}_{4}$ :
0.43-1.60 (mg L ${ }^{-1}$ ); Salinity: 0.070-0.100 (\%o); Chloride: 18.99-33.32 (mg L $\left.{ }^{-1}\right)$; total hardness: 11.00-30.00 ( $\left.{ }^{\circ} \mathrm{FS}\right)$; Ca: 24.53-61.70 $\left(\mathrm{mg} \mathrm{L}^{-1}\right)$; $\mathrm{Mg}$ : $9.93-44.83\left(\mathrm{mg} \mathrm{L}^{-1}\right)$. The measured of environmental parameters and their minimum, maximum and average values are given in the Table 1. Variations in these of environmental parameters according to the sampling stations and months are given in Figure 2. 
Table 1: The measured of environmental parameters and their minimum, maximum and average values

\begin{tabular}{lllll}
\hline & Abbreviation & Min. & Max. & Average \\
\hline Water temperature $(\mathrm{C})$ & $\mathrm{WT}$ & 2.00 & 29.00 & $16.48 \pm 10.027$ \\
Dissolved Oxygen $\left(\mathrm{mg} \mathrm{L}^{-1}\right)$ & $\mathrm{DO}$ & 3.40 & 15.73 & $7.65 \pm 3.813$ \\
Light permeability $(\mathrm{cm})$ & $\mathrm{LP}$ & 36.3 & 105.0 & $71.6 \pm 22.958$ \\
$\mathrm{pH}$ & $\mathrm{pH}$ & 7.53 & 8.63 & $8.29 \pm 0.283$ \\
Conductivity $\left(\mu \mathrm{S} \mathrm{cm}^{-1}\right)$ & $\mathrm{EC}$ & 388.00 & 613.67 & $523.03 \pm 88.695$ \\
Nitrate Nitrogen $\left(\mathrm{mg} \mathrm{L}^{-1}\right)$ & $\mathrm{NO}_{3}-\mathrm{N}$ & 0.00 & 9.89 & $3.49 \pm 2.934$ \\
Nitrite nitrogen $\left(\mathrm{mg} \mathrm{L}^{-1}\right)$ & $\mathrm{NO}_{2}-\mathrm{N}$ & 0.00 & 0.09 & $0.05 \pm 0.029$ \\
Ortho-Phosphate $\left(\mathrm{mg} \mathrm{L}^{-1}\right)$ & $\mathrm{o}-\mathrm{PO} 4$ & 0.000 & 0.068 & $0.010 \pm 0.020$ \\
Sulphate $\left(\mathrm{mg} \mathrm{L}^{-1}\right)$ & $\mathrm{SO}_{4}$ & 0.43 & 1.60 & $1.10 \pm 0.368$ \\
Salinity $(\%)$ & $\mathrm{Sal}$ & 0.070 & 0.100 & $0.082 \pm 0.010$ \\
Chloride $\left(\mathrm{mg} \mathrm{L}^{-1}\right)$ & $\mathrm{Cl}$ & 18.99 & 33.32 & $27.02 \pm 4.228$ \\
Total Hardness $\left({ }^{0} \mathrm{FS}\right)$ & $\mathrm{TH}$ & 11.00 & 30.00 & $23.79 \pm 4.705$ \\
Calcium $\left(\mathrm{mg} \mathrm{L}^{-1}\right)$ & $\mathrm{Ca}$ & 24.53 & 61.70 & $39.69 \pm 9.326$ \\
Magnesium $\left(\mathrm{mg} \mathrm{L}^{-1}\right)$ & $\mathrm{Mg}$ & 9.93 & 44.83 & $34.84 \pm 9.840$ \\
\hline
\end{tabular}

The average dissolved oxygen value was found as $7.65 \pm 3.813$. In freshwater ecosystems, the least dissolved oxygen amount for aquatic life may not be less than $5.0 \mathrm{mg} \mathrm{L}^{-1}$ (Kaya and Altındağ, 2007). The amount of zooplankton in fresh water is affected by temperature changes. Because temperature is the most important factor affecting the amount of nutrients in fresh water (Geller and Müller, 1981). In the present study, the lowest total Rotifera abundance was found in winter (53 934 ind $\mathrm{m}^{-3}$ ) when the water temperature reached its lowest values.

Most of the biochemical reactions in living and in the water depends on $\mathrm{pH}$, which is one of the most important parameters affecting distributions of zooplankton, and in terms of $\mathrm{pH}$ alkaline limit was reported 8.5 (Berzins and Pejler, 1987). According to the mean $\mathrm{pH}$ values (average $8.29 \pm 0.283$ ), Kadıköy Reservoir was rated as an alkaline water bearing reservoir. According to the level system of OECD for trophic status of lakes, a lake is considered as eutrophic if the measured Secchi depth is between 0.8 and $1.5 \mathrm{~m}$; mesotrophic if it is between 1.4 and $2.4 \mathrm{~m}$ and oligootrophic if it is between 3.6 and 5.9 m (Ryding and Rast, 1989).
According to this classification based on Secchi depths, Kadıköy Reservoir could be categorized as eutrophic since the measured Secchi depth is $71.6 \pm 22.958 \mathrm{~cm}$.

The comparison of the physic-chemical analyses results with National Standard for Turkish inland water revealed that comparison temperature, $\mathrm{pH}$, nitrate nitrogen, sulphate and phosphate were found at first and second quality level. In terms of dissolved oxygen the water was found at first quality level, nitrite nitrogen was found between second and third quality levels (Anonymous, 2016).

Zooplankton community structure: The identifications of the sampled material in Kadıköy Reservoir revealed presence of 33 species belonging to Rotifera (Table 2). When the sampling months were evaluated in terms of species diversity, highest number of species were found in May (23 species) followed by April (20 species), June (19 species), October (18 species) and March (16 species) while lowest species number was found in February (11 species). Asplanchna priodonta, Brachionus angularis, Filinia terminalis and Keratella cochlearis sampling in all months were the most 
common species during the study. Philodina megalotrocha, Collotheca ornata, Filinia longiseta, Hexarthra mira, Lecane lunaris, L. closterocerca, Polyarthra remata, Pompholyx sulcata, Synchaeta pectinat and Trichocerca similis, were sampling only in one month during the study.

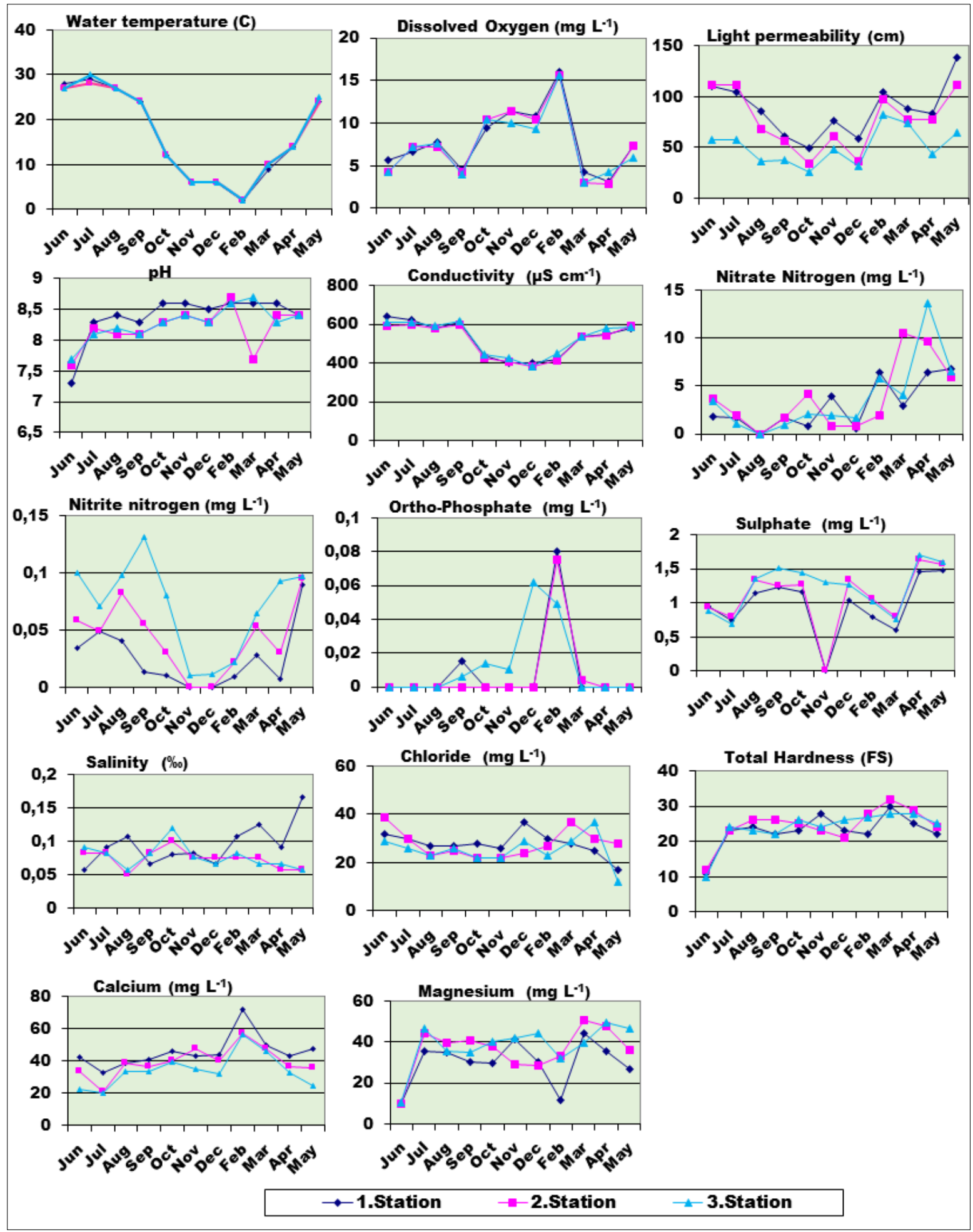

Figure 2: Variations in environmental parameters according to sampling stations and months 
Table 2: Rotifera species and minimum, maximum and average values of their annual in per $\mathrm{m}^{3}$

\begin{tabular}{|c|c|c|c|}
\hline ROTIFERA & Min. & Max. & Average \\
\hline Philodina megalotrocha Ehrenberg, 1832 & 0 & 1200 & $148 \pm 371.56$ \\
\hline Ascomorpha sp & 0 & 7813 & $2712 \pm 3249.61$ \\
\hline Asplanchna priodonta Gosse, 1850 & 5663 & 10878 & $8019 \pm 1893.12$ \\
\hline Asplanchna sieboldi (Leydig, 1854) & 0 & 1200 & $327 \pm 560.52$ \\
\hline Brachionus diversicornis (Daday, 1883) & 0 & 3563 & $606 \pm 1113.35$ \\
\hline Brachionus quadridentatus Hermann, 1783 & 0 & 3563 & $1405 \pm 1746.83$ \\
\hline Brachionus urceolaris Müller, 1773 & 0 & 12828 & $7466 \pm 4235.88$ \\
\hline Brachionus angularis Gosse, 1851: & 5663 & 9156 & $7310 \pm 1366.38$ \\
\hline Collotheca ornata (Ehrenberg, 1832) & 0 & 1200 & $218 \pm 485.42$ \\
\hline Conochilus dossuarius Hudson, 1875 & 0 & 456 & $41 \pm 137.49$ \\
\hline Euchlanis dilatata Ehrenberg, 1832 & 0 & 1200 & $192 \pm 380.84$ \\
\hline Filinia longiseta (Ehrenberg, 1834): & 0 & 1446 & $173 \pm 443.84$ \\
\hline Filinia terminalis (Plate, 1886) & 3534 & 7625 & $5406 \pm 1602.56$ \\
\hline Hexarthra mira Hudson, 1871 & 0 & 6125 & $878 \pm 2037.73$ \\
\hline Kellicottia longispina (Kellicott, 1879) & 0 & 7788 & $4701 \pm 2843.84$ \\
\hline Keratella tecta $($ Gosse, 1851$)$ & 0 & 6125 & $2234 \pm 2054.36$ \\
\hline Keratella quadrata (O.F.Müller, 1786) & 0 & 9156 & $5256 \pm 2923.88$ \\
\hline Keratella cochlearis (Gosse, 1851) & 1200 & 7663 & $5731 \pm 1907.06$ \\
\hline Lecane lunaris (Ehrenberg, 1832) & 0 & 5883 & $644 \pm 1774.51$ \\
\hline Lecane bulla (Gosse, 1886) & 0 & 2100 & $713 \pm 779.78$ \\
\hline Lecane luna (O.F.Müller, 1776) & 0 & 5838 & $1859 \pm 1897.64$ \\
\hline Lecane closterocerca (Schmarda, 1859) & 0 & 3554 & $365 \pm 1066.63$ \\
\hline Notholca squamula (O.F.Müller, 1786) & 0 & 5838 & $2780 \pm 2174.30$ \\
\hline Polyarthra remata Skorikov, 1896 & 0 & 3554 & $455 \pm 1115.76$ \\
\hline Polyarthra vulgaris (Carlin, 1943) & 0 & 7625 & $3404 \pm 2730.21$ \\
\hline Pompholyx sulcata (Hudson, 1885) & 0 & 3556 & $432 \pm 1096.76$ \\
\hline Synchaeta oblonga Ehrenberg, 1832 & 0 & 5838 & $1224 \pm 1889.80$ \\
\hline Synchaeta pectinata (Ehrenberg, 1832) & 0 & 1446 & $241 \pm 538.00$ \\
\hline Trichocerca similis (Wierzejski, 1893) & 0 & 1200 & $218 \pm 485.42$ \\
\hline Trichocerca capucina Wierzejski\&Zacharias, 1893 & 0 & 1446 & $740 \pm 695.98$ \\
\hline Trichocerca cylindrica (Imhof, 1891) & 0 & 3534 & $1417 \pm 1547.66$ \\
\hline Trichocerca pusilla (Jennings, 1903) & 0 & 2100 & $495 \pm 781.12$ \\
\hline Trichocerca sp. & 0 & 5838 & $2908 \pm 2027.23$ \\
\hline
\end{tabular}

The quantitative evaluation of the Rotifera samples revealed presence of an average of 70 472 ind $\mathrm{m}^{-3}$ in Kadiköy Reservoir (Table 2). When the sampling months were evaluated based on average individual values per $\mathrm{m}^{3}$, the maximum number of organism was found in May (100 901 ind $\mathrm{m}^{-3}$ ) followed by April (89 149 ind $\mathrm{m}^{-3}$ ) and the minimum was found in
February (46 203 ind $\mathrm{m}^{-3}$ ) followed by March (50 239 ind $\mathrm{m}^{-3}$ ) (Figure 3). Asplanchna priodonta was the leading species in terms of density (8 019 ind $\mathrm{m}^{-3}$ ), followed by Brachionus urceolaris $\left(7446\right.$ ind $\left.\mathrm{m}^{-3}\right)$, B. angularis (7 310 ind $\left.\mathrm{m}^{-3}\right)$, Keratella cochlearis $\left(5731\right.$ ind $\left.\mathrm{m}^{-3}\right), K$. quadrata (5 256 ind $\mathrm{m}^{-3}$ ) and Kellicottia longispina (4 701 ind $\mathrm{m}^{-3}$ ). The lowest density 
values were measured for Conochilus dossuarius (41 ind $\mathrm{m}^{-3}$ ), Philodina megalotrocha (148 ind $\left.\mathrm{m}^{-3}\right)$, Filinia longiseta (173 ind $\left.\mathrm{m}^{-3}\right)$ and Euchlanis dilatata $\left(192\right.$ ind $\mathrm{m}^{-3}$ ) (Table 2). The highest similarity was found between DecemberAugust and November-July months, while the lowest similarity was found between AugustMarch months (Figure 4).

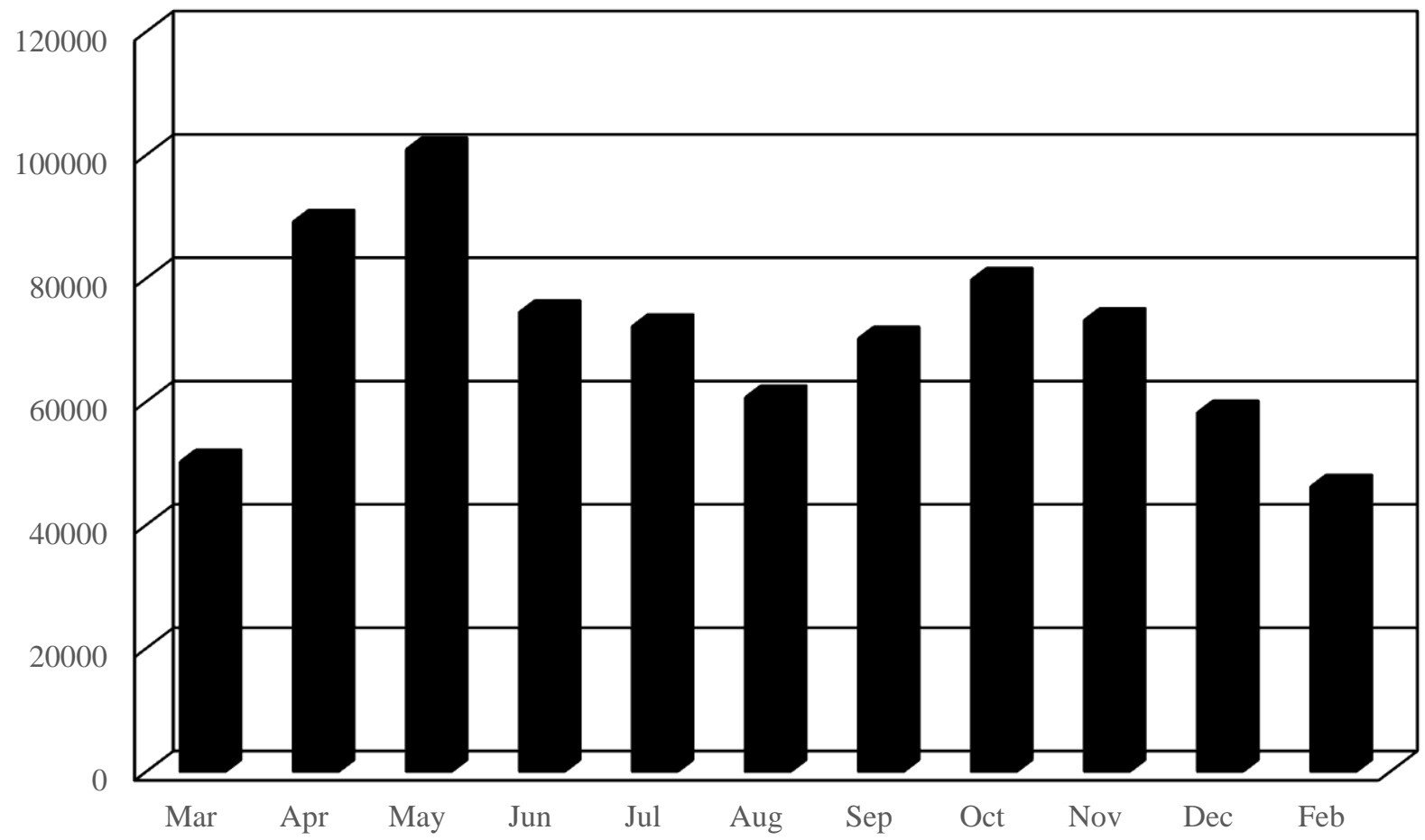

Figure 3: Total abundance of Rotifera according to the sampling months

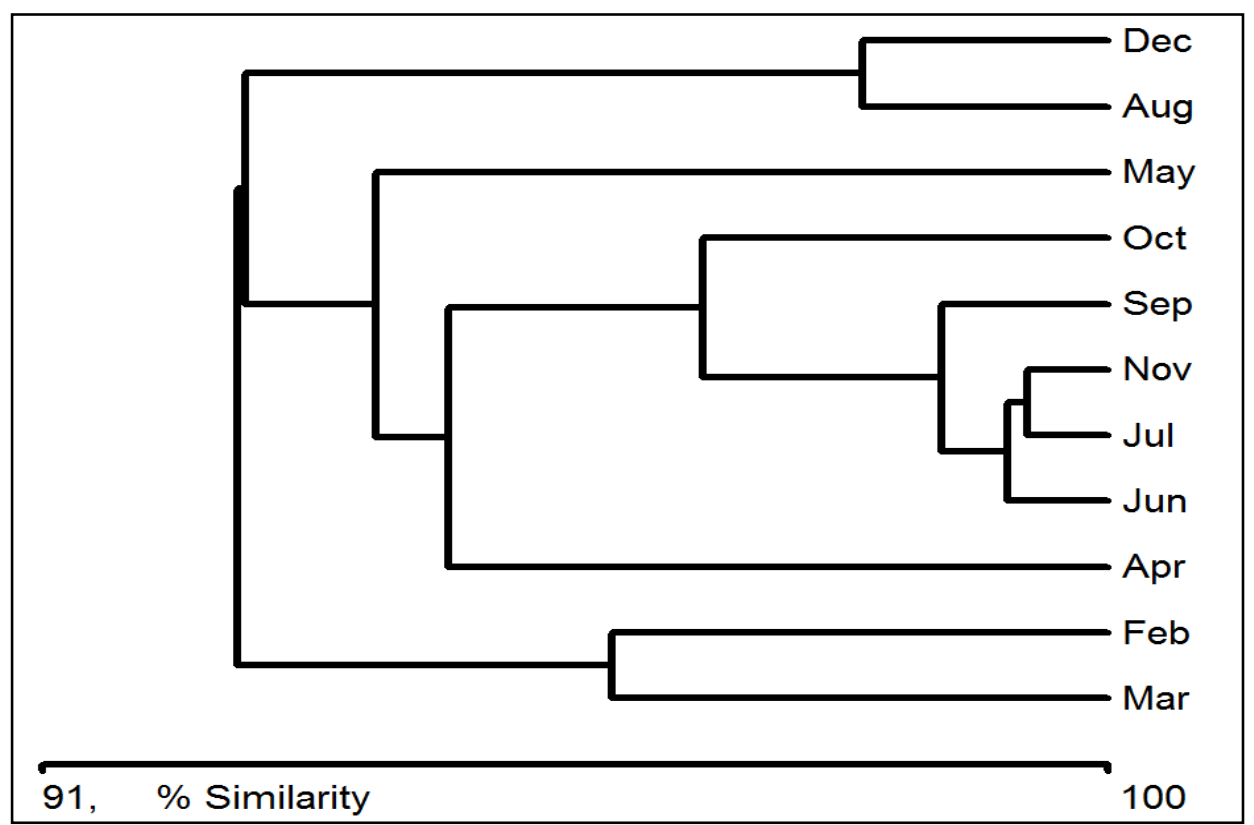

Figure 4: Bary-Curtis index similarity of zooplankton according to the sampling months 
The maximum number of Rotifera were recorded at $1^{\text {st }}$ station ( 81819 ind $\mathrm{m}^{-3}$ ). This is followed by the $2^{\text {nd }}$ and $3^{\text {rd }}$ stations with 69214 ind $\mathrm{m}^{-3}$ and 60383 ind $\mathrm{m}^{-3}$ respectively (Figure 5). Philodina megalotrocha $\left(1^{\text {st }}\right.$ and $3^{\text {rd }}$ stations), Asplanchna sieboldi, Collotheca ornate, Hexarthra mira, Trichocerca similis and $T$. pusilla $\left(1^{\text {st }}\right.$ and $2^{\text {nd }}$ stations $), \quad$ Lecane closterocerca, Polyarthra remata and Synchaeta pectinata $\left(2^{\text {nd }}-3^{\text {rd }}\right.$ stations) were found only in two stations, Conochilus dossuarius $\left(3^{\text {rd }}\right)$, Filinia longiseta $\left(1^{\text {st }}\right)$, Lecane lunaris $\left(2^{\text {nd }}\right)$, Pompholyx sulcata $\left(1^{\text {st }}\right)$ were found only in one station and other species were found at all stations. $2^{\text {nd }}$ station was the most species rich station with 29 species while followed by the $1^{\text {st }}$ station with 28 species and $3^{\text {rd }}$ station with 25 species

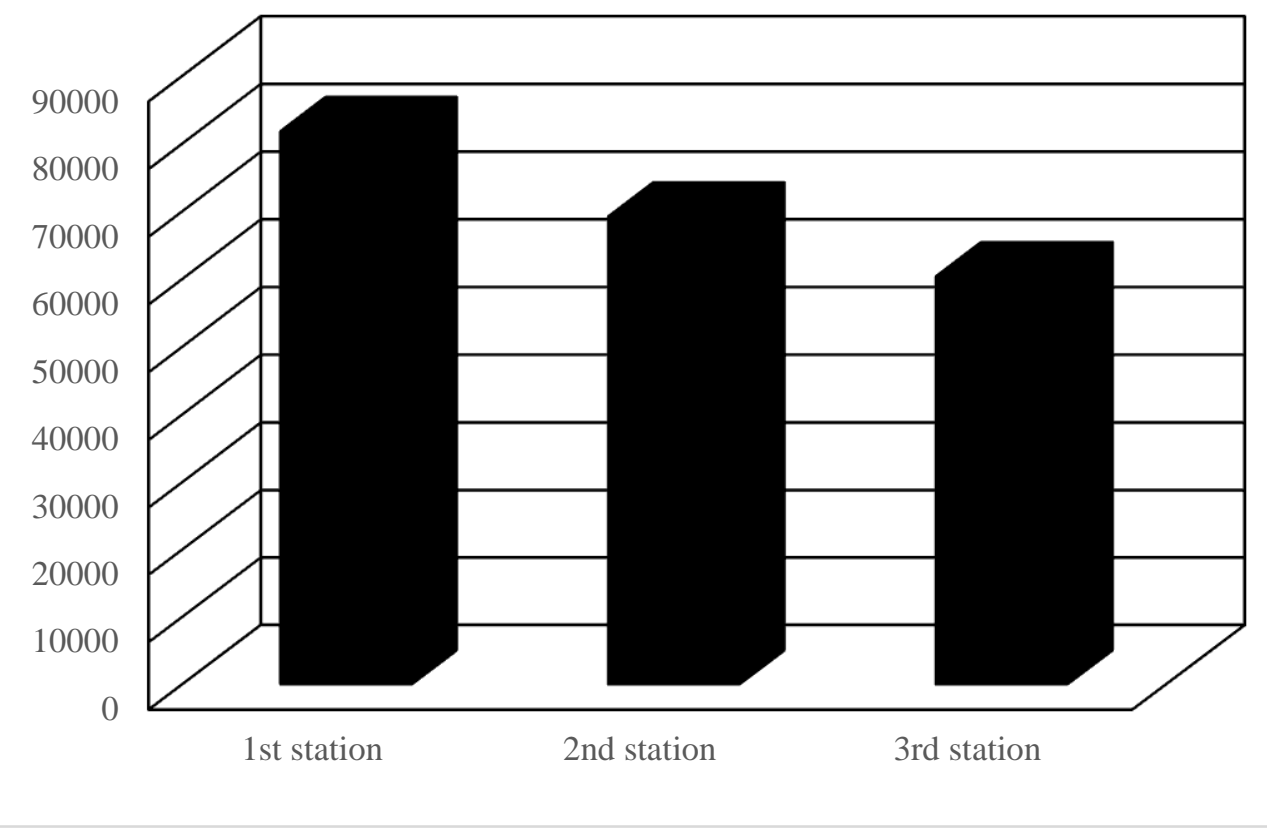

Figure 5: Abundance values of Rotifera according to sampling stations

When the sampling results were evaluated in terms of sampling month groups in their respective seasons, the maximum organism number was found in spring (83 458 ind $\mathrm{m}^{-3}$ ), followed by autumn (73 383 ind $\mathrm{m}^{-3}$ ) and summer (71 114 ind $\mathrm{m}^{-3}$ ) and the minimum was found in winter (53 934 ind $\mathrm{m}^{-3}$ ) (Figure 6). As species diversity, most species are found in spring and summer (28 species) while 22 species in autumn and at the winter 19 species were recorded. A decrease in species numbers in all the stations occurred in winter and an increase was observed in autumn and spring. The most species numbers were recorded in spring but fewer species numbers were observed in winter.
According to the Bary-Curtis index, seasonally are similar to each other over $85 \%$ (Figure 7).

All the species of Rotifera found in this study are shows widely distribution around the world and in Turkey (Segers, 2007; Ustaoğlu et al., 2012). The most common species in the Kadıköy Reservoir were Asplanchna priodonta, Brachionus angularis, Filinia terminalis and Keratella cochlearis found in all sampling months. In addition, Ascomorpha sp, Asplanchna priodonta, Brachionus quadridentatus, $B$. urceolaris, B. angularis, Filinia terminalis, Kellicottia longispina, Keratella tecta, $K$. quadrata, K. cochlearis, Lecane bulla, L. luna, Notholca squamula, Polyarthra vulgaris, 
Trichocerca capucina, T. cylindrica, which are cosmopolitan are widely distributed in Trichocerca sp. were the species found in all Turkey (Ustaoğlu et al., 2012). seasons during the study. These species most of

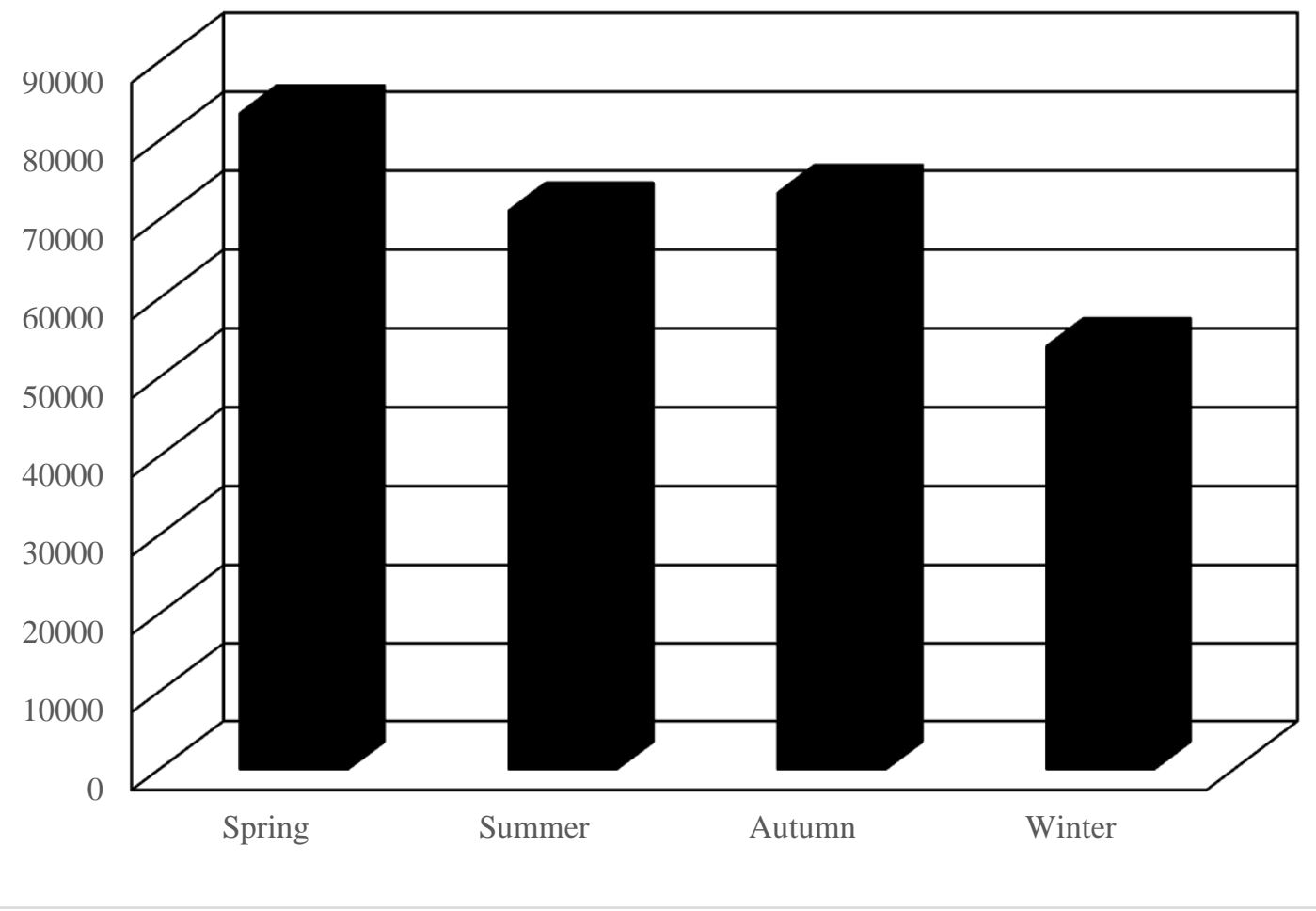

Figure 6: Abundance of Rotifera according to sampling to seasonally in Kadıköy Reservoir

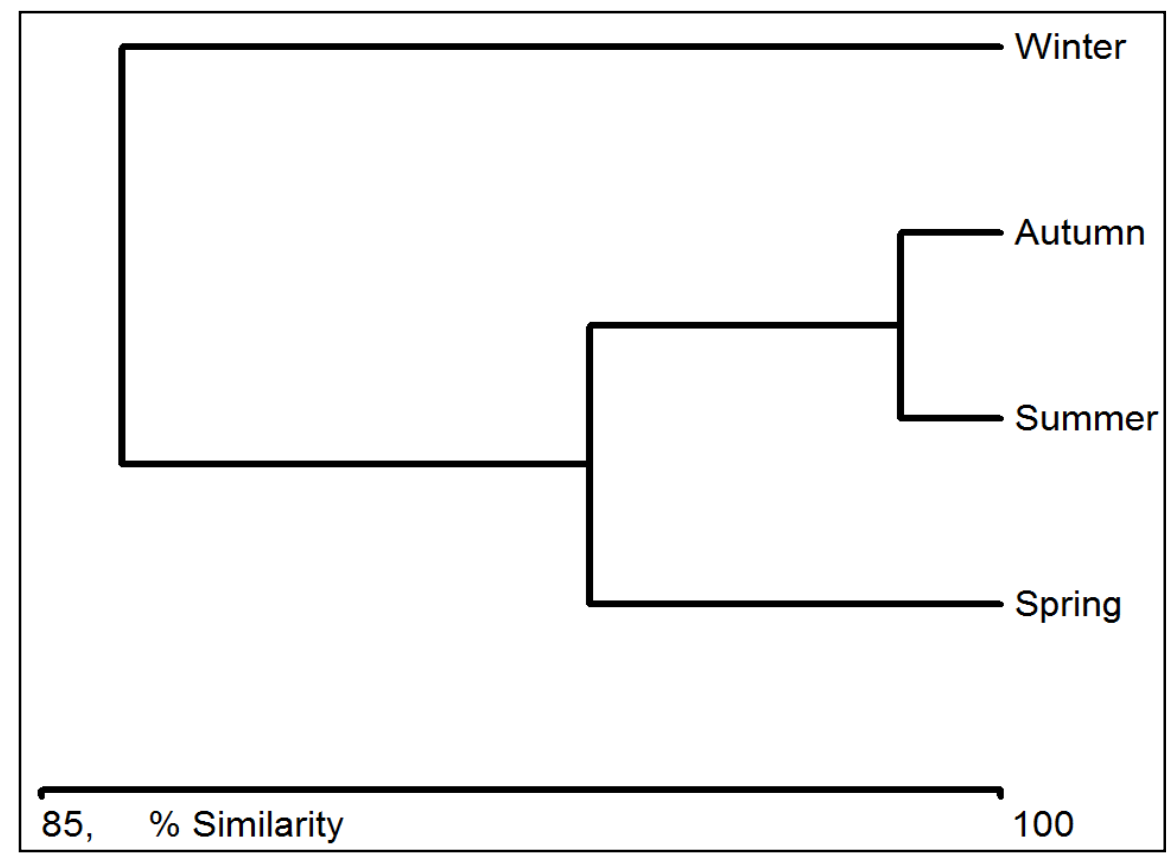

Figure 7: Bary-Curtis index similarity of zooplankton according to sampling stations 
Branchionus species were indicate eutrophic habitat. They also suggested the Brachionidae family and Brachionus species as indicators of highly trophic habitat (Radwan, 1984; Sladecek, 1983). In Kadıköy Reservoir 10 species (Brachionus diversicornis, B. angularis, B. quadridentatus, B. urceolaris Kellicottia longispina, Keratella cochlearis, $K$. quadrata, $K$. tecta and Notholca squamula) from Brachionidae were identified. Keratella cochlearis an indicator of eutrophic conditions was recorded in all the months during the study. According to these species, the Kadıköy reservoir showed mesotrophic property. But, to determine the trophic index of the lake, Brachionus:Trichocerca (QB/T) equality was used (Sladecek, 1983). According to this, while a quotient between one and two corresponds to mesotrophic conditions and a ratio of $>2$ is encountered in eutrophic lakes, a quotient of 1 indicates oligotrophic conditions. In this study, Kadıköy Reservoir was determined (4 species of Brachionus and 4 species of Trichocerca) QB/T $=1$. On the other hand, the reservoir showed oligotrophic property according to Rotifera index. However, the index was calculated as 5.7 according to the average abundances of these species determined in the reservoir (Brachionus 47961 ind $\mathrm{m}^{-3}$ and Trichocerca 8378 ind $\mathrm{m}^{-3}$ ), thus leading reservoir to show an eutrophic property.

\section{CONCLUSION}

Rotifera species in the Kadıköy Reservoir were evaluated both qualitatively and quantitatively. A total of 33 Rotifera species were determined in the qualitative evaluation of plankton samples. The quantitative evaluation of the samples revealed an average value of 70 472 ind $\mathrm{m}^{-3}$ in the reservoir. While the maximum organism was found in spring (83 458 ind $\mathrm{m}^{-3}$ ) at

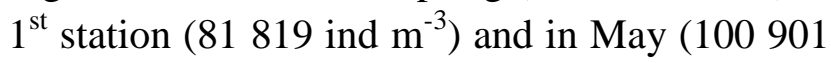
ind $\mathrm{m}^{-3}$ ), the lowest value found in winter (53 934 ind $\left.\mathrm{m}^{-3}\right), 3^{\text {rd }}$ station $\left(60383\right.$ ind $\left.\mathrm{m}^{-3}\right)$ in
February (46 203 ind $\mathrm{m}^{-3}$ ). When we evaluate the species identified in the reservoir, the distribution of the individuals that make up the Rotifera fauna and physical-chemical parameters as a whole, it has been concluded that Kadıköy Reservoir is in meso-eutrophic character in terms of zooplankton.

\section{REFERENCE}

Anonymous, 2016. Yerüstü Su Kalitesi Yönetmeliği. Resmi Gazete, 16 Ağustos 2016 Çarşamba, Sayı: 29779.

Ayvaz M, Tenekecioğlu T, Koru E, 2011. Avşar Baraj Gölü'nün (Manisa-Türkiye) Trofik Statüsünün Belirlenmesi. Ekoloji, 20 (81): 37-47

Bekleyen A, 2003. A taxonomical study on the zooplankton of Göksu Dam Lake (Diyarbakır). Turkish Journal of Zoology, 27: 95-100.

Berzins B, Pejler B, 1987. Rotifer occurrence in relation to pH. Hydrobiologia, 147: 107-116.

Bozkurt A, Sagat Y, 2008. Birecik Baraj Gölü Zooplanktonunun Vertikal dağllımı. Journal of Fisheries Sciences.com, 2 (3): 332-342.

Bulut H, Saler S, 2014. Zooplankton of Beyhan Dam Lake (Elazı ğ- Turkey). Turkish Journal of Science \& Technology, 9 (1): 23-28.

Buyurgan Ö, Altındağ A, Kaya M, 2010. Zooplankton community structure of Asartepe Dam Lake (Ankara, Turkey). Turkish Journal of Fisheries and Aquatic Sciences, 10: 135-138.

De Manuel Barrabin J, 2000. The Rotifers of Spanish Reservoirs: Ecological, Systematical and Zoogeographical Remarks, Limnetica, 19: 91-167.

Dirican S, Musul H, 2008. Çamlıöze Baraj Gölü zooplankton faunası üzerine bir çalışma. Sakarya Üniversitesi Fen Bilimleri Dergisi, 12 (1): 17- 21.

Edmondson W. T, 1959. Methods and Equipment in Freshwater biology 2nd ed. John Willey and Sons. Inc., NewYork, 420-1202.

Erdoğan S, Güher H, 2012. The Rotifera Fauna of Turkish Thrace (Edirne, Tekirdağ, Kırklareli). Journal of Fisheries Sciences.com. 6 (2): 132-149.

Geller W, Müller H, 1981. The filtration ap-paratus of Cladocera: filter mesh-sizes and their implications on food selectivity. Oecologia, 49: 316-321.

Güher H, 2014. A Checklist for Zooplankton (Rotifera, Copepoda, Cladocera) of European Turkey Inland Waters. Ege Journal of Fisheries and Aquatic Sciences 31(4): 221-225.

Herzig A, 1987. The Analysis of Planktonic Rotifer Populations: a Plea for Long-Term Investigations. Hydrobiologia, 147: 163-180. 
Jackson DC, Schmitz E.H, 1987. Zooplankton abundance in vegetated and non-vegetated areas: Implications for Fisheries Management. Process of South Association of Fish Wildlife Agent. 41: 214-220.

Kaya M, Altındağ, A, 2007. Zooplankton fauna and seasonal changes of Gelingüllü Dam Lake (Yozgat, Turkey). Turkish Journal of Zoology, 31: 347-351.

Koste W, 1978. Die Radertiere Mitteleuropas I.Tafelband. Berlin, Studgart, $670 \mathrm{p}$.

Krebs CJ, 1999. Ecological Methodology. Addison Wesley Longman, Inc., Menlo Park, California. $620 \mathrm{p}$.

Mis DÖ, Aygen C, 2010. Buldan Baraj Gölü (Denizli) Planktonu ve Mevsimsel Değişimi. Ege Journal of Fisheries and Aquatic Sciences, 27 (3): 113-120.

Radwan S, 1984. The influence of some abiotic factors on the occurrence of rotifers of Leczna and Wladowa Lake District. Hydrobiology. 112: 117-124.

Rocha O, Matsumura-Tundisi T, Espindola, ELG, Roche KF, Rietzler AC, 1999. Ecological theory applied to reservoir zooplankton. p. 29-51. In: Theoretical Reservoir Ecology and its Applications (Eds. J.G. Tundisi, and M. Straskraba), International Institute of Ecology, Brazilian Academy of Sciences. Backhuys Publishers, Leiden, Holland.

Ruttner-Kolisko A, 1974. Plankton Rotifers Biology and Taxonomy. Stutgart: Biological Station Lunz of the Austrian Academy of Science.

Ryding SO, Rast W, 1989. The Control of Eutrophication of Lakes and Reservoirs. Man Biosphere Series, Parthenon Publication Group, Vol 1, USA.
Saler S, 2017. Diversity and abundance of zooplankton in Medik Reservoir of Turkey. Maejo International. Journal of Science and Technology, 11(02): 126132.

Saler S, Alış İN, 2014. Zooplankton of Hancağız Dam Lake (Gaziantep - Turkey). Journal of Survey in Fisheries Science, 1(1): 36-45.

Sampaio EV, Rocha O, Matsumura-Tundisi T, Tundisi JG, 2002. Composition and abundance of zooplankton in the limnetic zone of seven reservoirs of the Paranapanema River. Brazilian Journal of Biology, 62: 525-545.

Segers H, 2008. Global diversity of Rotifers (Rotifera) in freshwater. Hydrobiologia, 595: 49-59.

Sladecek V, 1983. Rotifers as indicators of water quality. Hydrobiology, 100: 169-201.

Tuna A, Ustaoğlu MR, 2016. Kemer Baraj Gölü (AydınTürkiye) zooplankton faunas1. Limnofish-Journal of Limnology and Freshwater Fisheries Research, 2 (2): 95

Ustaoğlu MR, Altındağ A, Kaya M, Akbulut N, Bozkurt A, Özdemir Mis D, Atasagun S, Erdoğan S, Bekleyen A, Saler S, Okgerman H C, 2012. A check list of Turkish Rotifers. Turkish Journal of Zoology, 36 (1): 607-622.

Ustaoğlu RM, 2004. Türkiye içsuları zooplankton kontrol listesi. Ege Üniversitesi Su Ürünleri Dergisi, 21 (34): 191-199.

Yıldız Ş, 2012. Zernek-Baraj Gölü (Van/Türkiye) zooplankton faunası. Biyoloji Bilimleri Araştırma Dergisi. 5 (1): 57-59. 